\title{
Keczer Gabriella
}

Szegedi Tudományegyetem JGYPK Művelődéstudományi Tanszék

ORCID:0000-0003-0145-0380

\section{A felsőoktatás nemzetköziesítésének kulturális dimenziói}

\begin{abstract}
Absztrakt
A magyar felsőoktatás nemzetköziesedése révén a hazai felsőoktatásban is egyre nagyobb számban és arányban tanulnak más országokból érkezők, ennek megfelelően a külföldi hallgatók fogadásának, oktatásának kulturális aspektusai is egyre fontosabbá válnak számunkra. Tanulmányomban nemzetközi és hazai szakirodalmi források, kutatások alapján azt mutatom be, hogy milyen kihívásokkal járhat a külföldi hallgatók saját, "hozott" kultúrájának és a lokális szokásoknak és értékeknek a találkozása, ütközése; milyen oktatói és szervezeti kompetenciák szükségesek az eredményes interkulturális oktatáshoz; és milyen kedvező kulturális hatásokkal jár a külföldi hallgatók jelenléte megfelelő szervezeti és pedagógiai megoldások esetén.
\end{abstract}

Kulcsszavak: felsőoktatás, nemzetköziesítés, külföldi hallgatók, nemzetközi tanterem, interkulturális kompetenciák, interkulturális tanulás

\begin{abstract}
Cultural Dimensions of the Internationalization of Higher Education With the ongoing internationalization of Hungarian higher education, both the number and the rate of international students are increasing. Thus, all the aspects of internalization, including the cultural one, are acquiring importance. Our study discusses the challenges that emerge with the clash of the local culture and the norms and values brought by the foreign students; the individual and organizational competencies necessary to effective intercultural teaching and learning; the cultural benefits brought about by the presence of foreign students on campus.
\end{abstract}

Keywords: higher education, internalization, foreign students, international classroom, intercultural competencies, intercultural learning

\section{Bevezetés}

A felsőoktatás nemzetköziesítésének két pillére a külföldön történő aktivitás (internationalization abroad), melynek része az oktatók és hallgatók kiutazása, intézmények, kampuszok létrehozása, kihelyezett képzések folytatása külföldön, valamint bizonyos otthoni tevékenységek (internationalization at home), például a kurrikulum, a tananyag nemzetköziesítése, idegen nyelvủ képzések, kurzusok indítása, vendégoktatók és külföldi hallgatók fogadása az intézményekben. Ez utóbbinak különösen nagy jelentősége van az olyan országok, például Magyarország esetében, amelyeknek szúkösebbek a lehetőségei a külföldi aktivitás, például kihelyezett kampuszok létesítésének terén. Az otthon történő nemzetköziesítéssel, ezen belül különösen a külföldi hallgatók fogadásával az ilyen országok intézményei is biztosítani tudják a hazai hallgatók számára a nemzetközi oktatási környezetet.

A magyar felsőoktatás nemzetköziesedése révén a hazai felsőoktatásban is egyre nagyobb számban és arányban tanulnak más országokból érkező hallgatók (1. és 2. ábra), és egyre több intézmény kapcsolódik be a külföldi hallgatók képzésébe. Ezzel összefüggésben az intézmények nemzetköziesítésével kapcsolatos és a külföldi hallgatók körében végzett hazai kutatások is megjelentek és egyre gazdagabbá váltak (lásd például Berács et al. 2014; Berács, Malota 2011; Erdei et al. 2018; Erdei 2018; Hangyál, Kasza 2018; Kovács et al 2015; Lannert 2018a, 
2018b; Malota et al. 2014; Malota 2013, 2016; Tempus 2017, 2019a, 2019b, 2019c, 2020a, 2020b). A magyar felsőoktatásban megjelenő külföldi állampolgárok száma az ezredfordulót követően folyamatosan emelkedik. A 2001-es 11783 főről három és egynegyedszeres növekedéssel a 2019/2020-as tanévre eljutottunk az akkori érték 326\%-ára, azaz 38422 före. (Tempus 2020a: 4) Meghatározó tendencia, hogy az elmúlt tíz évben négy szomszédos ország (Szerbia, Ukrajna, Románia és Szlovákia) hallgatói létszáma, vagyis elsősorban az itt tanuló külhoni magyarok száma csökken. Bár arányuk a külföldi hallgatók között továbbra is meghatározónak tekinthető, ugyanakkor ez az arány fokozatosan egyre kisebb. Az elmúlt években több ország vált meghatározó küldő országgá, ilyen például Kína és Törökország. (Hangyál, Kasza 2018: 7) Ennek megfelelően a nemzetköziesítés kulturális aspektusai, a külföldi hallgatók megjelenésével járó kulturális kihívások és lehetőségek is egyre fontosabbá válnak számunkra.

1. ábra: Külföldi hallgatók számának alakulása Magyarországon (2006-2020)

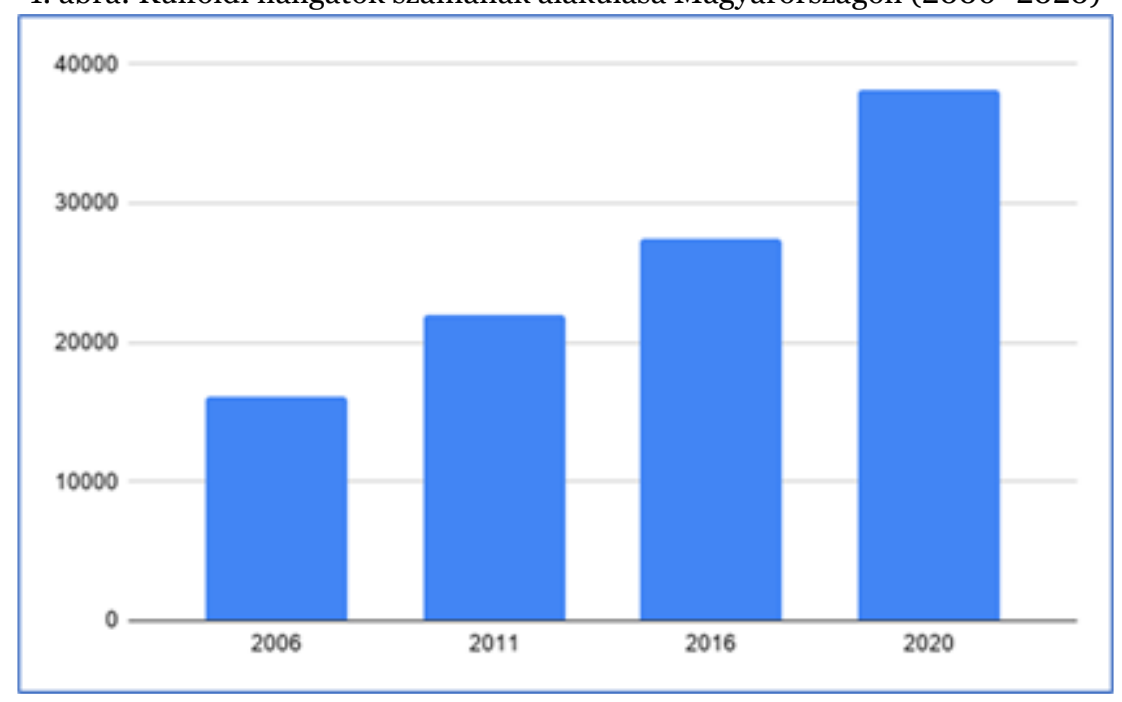

Forrás: KSH, OH, Tempus alapján saját szerkesztés

2. ábra: Külföldi hallgatók arányának alakulása Magyarországon (2006-2020)

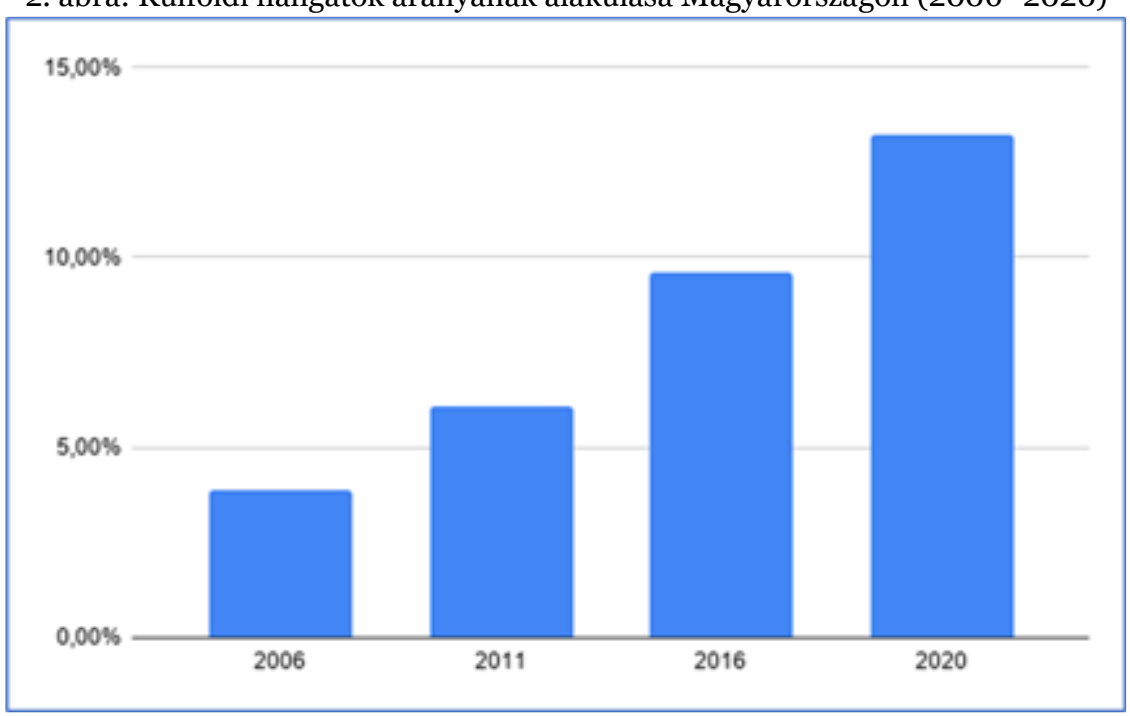

Forrás: KSH, OH, Tempus alapján saját szerkesztés

\section{Kihívások - miért kell foglalkozni a kulturális különbségekkel a nemzetközi tanteremben?}

A tanulás szocio-kulturális elméletei rámutatnak arra, hogy a tanulás ugyan „egyénileg konstruált, de társadalmilag meghatározott és kultúrába ágyazott, a kultúra által közvetített folyamat” (Ryan 2011: 636). Mint Rizvi rámutat, éppen ezek a társadalmi viszonyok és kulturális gyakorlatok formálják a tanulás és a tanítás gyakorlatát (Rizvi 2010 idézi Ryan 2011). Az eltérő 
kultúrában szocializálódott emberek eltérően viszonyulnak a tudáshoz, tanuláshoz, a tanárdiák viszonyhoz, az együttmúködéshez; a kulturális szokások, normák meghatározóan jelen vannak a tanítási-tanulási tevékenységekben. Ez az oka annak, hogy a tanítási-tanulási folyamat szereplőinek - hazai és külföldi hallgatók, oktatók - a kulturális különbségekkel is meg kell küzdeniük a nemzetközi tanteremben (international classroom). Maga az egyetem sem csak fizikai hely, hanem komplex jelenség, amelyet a szervezeti kultúra különböző elemei szabályok, mítoszok, nyelvhasználat, rituálék, közösségi kapcsolatok, szokások stb. - formálnak, így a külföldi hallgatók nem csak egy intézménybe, hanem egy kulturális mikrokozmoszba érkeznek.

Az úgynevezett „kulturális sokk” széleskörüen tárgyalt jelenség a szakirodalomban. A külföldi hallgatóknak saját kulturális értékeik, normáik, szokásaik és nyelvük van, ezek pedig alapvetően különbözhetnek a fogadóországétól. Ilyen kritikus, az egyes kultúrákban jelentős eltérést mutató tényező például az időhöz, a felelősséghez, a versengéshez való viszony, a barátság, a férfi-nő kapcsolat. Ezen tényezők megjelennek a tanulási-tanítási folyamatban is, befolyásolják például a határidőkkel, a csoportmunkával, a szerzői jogokkal, a tanár-diák viszonnyal kapcsolatos attitűdöket. A külföldi hallgatók akár a legjelentéktelenebbnek tűnő különbségeket is kulturális sokként élhetik meg, ez pedig mentális, pszichológiai problémákhoz vezethet (Jourdini 2012). A nyelvhasználat is hozzájárulhat a kulturális sokkhoz: mindenki a saját kulturális kontextusának megfelelően használja a nyelvet, és előfordulhat, hogy a más kultúrából érkezők ismerik ugyan a szavakat, de azok más jelentést hordoznak számukra (Teekens 2003). Ez a probléma hozzáadódik ahhoz a kihíváshoz, hogy a külföldi hallgatók - és Magyarország esetében az oktatók - nem az anyanyelvükön kommunikálnak, ezért a másodlagos jelentéstartalmakat, indirekt üzeneteket nehezebben adják át és fogadják be. A külföldi hallgatók számára stresszforrás lehet, hogy nem értik a szóvicceket és a kulturális utalásokat, illetve az oktatók vagy hallgatótársak érintenek bizonyos tabukat, a külföldi hallgatók számára kényes témákat. Fontos megjegyezni, hogy a fenti jelenségek nem csak a külföldiek, hanem a velük együtt tanuló hazai hallgatók és oktatók számára is kihívást jelentenek a nemzetközi tanteremben.

Hazai tapasztalatok is igazolják, hogy külföldiként számos kihívással szembesül az ide érkező hallgató, melyek közül a Tempus felmérése szerint a beilleszkedés az egyik legfőbb probléma: a kevés külső kapcsolat, a saját közösségbe zárkózás okán elmagányosodhatnak, ami a hallgatói lemorzsolódás fő katalizátora az első időszakban. A külföldi hallgatóknak az új felsőoktatási intézmény mellett egy új kulturális közeggel is meg kell birkózniuk. Egyik visszatérő alapélményük, hogy tanulmányaik elején magányosak, vagy pedig egyfajta ismert komfortzónában, a saját nemzeti közösségeiken belül mozognak. (Tempus 2019a) A szakirodalom ezeket a jelenségeket a kulturális magány (cultural loneliness), a kulturális gettók, illetve silók (cultural ghettos, silos) fogalmaival írja le. Jourdini (2012) szerint a kulturális gettók elsősorban azért alakulnak ki az amerikai egyetemeken, mert a kulturális sokkhatás alatt álló külföldi hallgatók a saját országukból, térségükból érkezett társaik körében találnak vigasztaló, megnyugtató, szeretetteljes közegre. Potts megfigyelése szerint a nemzetek szerinti elkülönülés annál inkább jellemző, minél nagyobb a külföldi hallgatók száma az adott intézményben (Potts 1991; idézi Bowry 2002). Sajnos ez éppen a valódi nemzetközi tanulási környezet kialakulását gátolja, és a hallgatókat megfosztja a más nemzetiségúekkel való interakcióktól és azok kedvező hatásaitól.

A kulturális sokk mellett az úgynevezett akadémiai kulturális sokk jelenségével is foglalkoznunk kell a külföldi hallgatókkal összefüggésben. A hallgatók tanulási stratégiája és a tanuláshoz-tanításhoz való általános viszonya jelentős részben nemzeti és kulturális meghatározottságú (Teekens 2003). Eszerint különbözhet például a kooperatív, kompetitív és individualista tanulási stratégia; a tanítási-tanulási stílus, ezen belül a strukturált vagy strukturálatlan, magoláson vagy értelmezésen alapuló tanulás (rote learning, deep learning); a részvételi hajlandóság; az együttmúködési készség; az önirányított tanulásra való képesség; az önálló véleményalkotás és kritikai gondolkodás; a plagizálás definíciója és megítélése vagy az intelligencia értelmezése - ezek a legmeghatározóbb eltérések az egyes akadémiai kultúrákban (Ward 2006; Ballard 1995; Mills 1997 idézi Egege, Kutieleh 2004). Számos tanulmány írja le meglehetősen plasztikusan ezeket a különbségeket. Ezek szerint bizonyos kultúrákban a hallgatók 
passzív szerepben vannak, éppen úgy, mint a hívek a templomban, a nagy tiszteletben áló tanárok pedig olyanok, mint a papok, szentbeszédet tartanak. A tanár-diák viszony ennek megfelelően erősen formális. Az ilyen tanteremben alig van interakció, legfeljebb egy-egy utasítás hangzik el bizonyos szövegrészek felolvasására, a hallgatók pedig némán jegyzetelnek. Az előadót megszakítani, kérdéseket feltenni, vitára ingerlő megjegyzéseket tenni tiszteletlenségnek számít. A hallgatók igénylik, hogy a tanár rendszeresen kijavítsa őket. Sokhelyütt a plagizálás és a puskázás elfogadott. Ezzel szemben például az Egyesült Államokban a hallgatókat kifejezetten arra bátorítják, sőt, el is várják tőlük, hogy aktívan vegyenek részt az órai munkában, kérdéseket tegyenek fel. (Jourdini 2012; Godwin 2009) A különböző akadémiai kultúrák ütközése jelentős konfliktusok forrása. Az egyéni magoláshoz és a tények reprodukálásához szokott hallgatók nehezen tudnak alkalmazkodni egy olyan oktatási rendszerhez, amelyben a problémamegoldás, a kooperáció és a kritikus gondolkodás alapvető elvárás. A plagizálás elfogadottsága bizonyos akadémiai kultúrákban teljes mértékben ellentmond a nyugati világ tudományos elvárásainak.

Fontosnak tartjuk azonban Biggs (1997 idézi Egege; Kutieleh 2004) felvetését, miszerint óvatosan kell bánnunk a fent részletezett különbségekből levonható következtetésekkel. Mills bár nem vitatja, hogy bizonyos karakterisztikák erőteljesen jellemzik a Konfuciánus (Confucian-heritage) oktatási rendszereket -, felhívja a figyelmet arra, hogy a délkelet-ázsiai hallgatók sem tekinthetôk homogén csoportnak, hiszen az ebből a térségből érkezók között is jelentős különbségek vannak. Azt is hangsúlyozza, hogy a magolás nem feltétlenül jelent felszínes tanulást, a passzivitás pedig elsősorban azt a magatartást tükrözi, amit a hallgatók helyénvalónak tartanak az adott környezetben. (Mills 1997 idézi Egege; Kutieleh 2004)

Különösen érzékeny metszéspontja a kulturális és akadémiai dimenzióknak a szociális szerepmintázatok és a tanár-diák viszony összefüggése. Az oktatási környezet olyan mikrokozmosz, amely a befoglaló társadalmi rendszer része, és annak értékeit, hagyományait, gyakorlatait tükrözi. Ennek megfelelően a tanítás-tanulás során mutatott viselkedést is a nem, az életkor és az ezeknek megfelelő társadalmi szerepmintázat határozza meg. A különböző kultúrákban ezek a szerepmintázatok eltérőek. Teekens szerint az olyan kultúrából érkező hallgatóknak, amelyben a férfi és a női szerepek teljesen elkülönülnek, nehéz lehet elfogadni egy nőt a tanári szerepben, hiszen ez náluk a férfiak territóriuma. Még ha a hallgatók el is fogadják a nőket tanári szerepben a fogadó intézményben, a mélyen beléjük vésődött nemi szerepmintázatok megnehezíthetik a kommunikációt és az interakciót az adott oktatóval. Ugyanez a női hallgatótársakkal való együttmúködést is akadályozhatja. Bizonyos helyzetekben a nem és az életkor - egy fiatal tanárnő esetében - egymást erősítve nehezíthetik az elfogadást. (Teekens 2003)

Témánk szempontjából fontos a kulturális alkalmazkodás (cultural adjustment, acculturation) és a fordított kulturális sokk (reverse cultural shock) kérdése is. Amennyiben a külföldi hallgatók akár kulturális, akár akadémiai szempontból alkalmazkodnak, azaz idomulnak a fogadó intézmény domináns rendszeréhez, hazatérve szembesülhetnek a fordított kulturális sokk traumájával. Nilsson és Anderson (2004) véleményével egyetértve: tekintettel arra, hogy a külföldön tanuló hallgatók egy része vissza kíván térni a hazájába, a fogadó intézmények célja nem lehet az akulturalizáció. Sokkal inkább arra kell megtanítaniuk a hallgatókat, hogy hogyan legyenek kettős kultúrájúak (bicultural), hogyan funkcionáljanak hatékonyan két - vagy akár több - kultúrában is. Ehhez arra van szükség, hogy az intézmények és az oktatók tisztában legyenek a kultúra és a tanulási stílus összefüggéseivel, a kulturális és akadémiai különbségekkel, és megfelelően kezeljék azokat (Lemke-Westcott, Johnson 2013 idézi Bedenlier, ZawackiRichter 2015). A felsőoktatás nemzetköziesítése érdekében mind egyéni, mind szervezeti szinten szükség van az interkulturális érzékenység és kompetenciák fejlesztésére (Otten 2000). A következő fejezetben ezzel a kérdéskörrel foglalkozunk.

\section{Feltételek - mire van szülkség egyéni és intézményi szinten az eredményes interkulturális oktatáshoz?}

A globalizáció megváltoztatta azt a társadalmi és politikai közeget, amelyben az egyetemek múködnek, és ma a felsőoktatási intézmények olyan transznacionális tereknek tekinthetók, amelyekben a kapcsolatok és az interakciók átnyúlnak a határokon és a nemzetállamokon (Rizvi 2010 idézi Ryan 2011). A multikulturalizmus immár otthon, lokális szinten is áthatja az 
akadémiai szférát, a nemzetköziesítés otthoni tevékenységei, a külföldi intézményekkel való együttműködések, a globálissá vált tudományosság, a külföldi hallgatók és vendégoktatók révén. Ez mind az egyének - oktatók, adminisztratív személyzet -, mind a szervezetek szintjén új elvárásokat támaszt.

Ami az egyéni szintet illeti, az olyan országokban, amelyek történelmi okok miatt bizonyos ideig csak korlátozottan vehettek részt a nemzetközi tudományos életben, és az oktatók tapasztalatszerzése nemzetközi szinten kevésbé volt lehetséges, különösen fontos Teekens megállapítása, mely szerint a nemzetközi tanteremben a tanításhoz és a tanuláshoz teljesen másra van szükség, mint tisztán nemzeti keretek között. Ehhez az oktatóknak olyan speciális kompetenciákat kell elsajátítaniuk, amelyek birtoklása nem várható el tôlük pusztán nemzeti akadémiai háttérrel. (Teekens 2000) Paige és Goode (2009 idézi Gopal 2011) szerint az oktatók nincsenek tisztában azzal, hogyan kell kulturálisan érzékeny módon reagálni, ezért nem tudnak eredményesen kommunikálni és dolgozni más kultúrából érkezett hallgatókkal. Ez nem meglepő, hiszen, ahogyan Ward (2006) megállapítja, a tanárképzésből gyakran hiányzik az ehhez szükséges kompetenciák tanítása. Ráadásul a felsőoktatásban oktatók jelentős része egyáltalán nem részesült pedagógiai felkészítésben. Deardorff (2009) és Verbik (2007 idézi Gopal 2011) szerint a felsőoktatás globalizálódásával elengedhetetlenné vált az egyetemi oktatók felkészítése arra, hogy multikulturális környezetben eredményesen tanítsanak.

Az interkulturális kompetenciáknak számos megközelítését kínálja a szakirodalom. Hiller és Wozniak szerint az interkulturálisan kompetens személy „érzékenységet mutat más kultúrák iránt, és képes a kulturális “mássághoz” bizonytalanság-érzet és félelem nélkül közelíteni” (Hiller, Wozniak 2009 idézi Gopal 2011: 374). Deardorff (2009 idézi Gopal 2011) a kultúraközi szituációkban való hatékony és megfelelő kommunikáció képességével azonosítja az interkulturális kompetenciát, és az ehhez szükséges attitűdöt, tudást és készségeket veszi számba. Ezeket a következőkben Gopal (2011) alapján foglaljuk össze.

Az interkulturális kompetenciákkal rendelkező személy attitűdjére jellemző, hogy nagyra értékel más kultúrákat, nyitott és befogadó (Paige, Goode 2009), törekszik más kultúrák megismerésére (Deardorff 2009), nem ítélkező (Dunn, Wallace 2006), elutasítja az etnocentrikus szemléletet és viselkedést (Teekens 2003). Az etnocentrizmus Adler (1991) szerint az a meggyőződés, hogy az adott kultúra magasabb rendủ a többinél. Ez a más kulturális hátterű emberekkel való kommunikációtól való idegenkedéshez vezet (Ellis 2006), olyan bináris "mi” és “ők” gondolkodáshoz, melyben az “ők” kevésbé értékesek, ebből adódóan rájuk kell kényszeríteni a "mi" nézeteinket (Kim, Hubbard 2007). Az interkulturális kompetenciákkal rendelkező személy tudásának fontos eleme a kulturális tudatosság (Paige, Goode 2009). Ez egyrészt a saját kulturális normáink és elvárásaink ismeretét, másrészt a kulturális különbségek felismerését jelenti. Ide tartozik például a nemi szerepek eltérő felfogása a különböző kultúrákban, a tudatos, az eltérésekre tekintettel lévő verbális és nonverbális kommunikáció (szemkontaktus, érintés, közelség). Csak úgy érthetjük meg a más kultúrából érkezőket, ha van bizonyos tudásunk arról a rendszerről, amely formálta őket (Teekens 2003). Az interkulturális készségekhez tartozik az önreflexió, amely lehetővé teszi, hogy az oktatók kritikusan szemléljék saját interakcióikat a más kultúrákból érkezőkkel, valamint az alkalmazkodó-készség, az érzelmek és a konfliktusok kezelése.

Az oktatók interkulturális fejlődésének, a külföldi hallgatókhoz való hozzáállásának négy fázisa különíthető el Carroll (2012) alapján. Az első a tagadás fázisa, melyben az oktatók még nem ismerik fel a külföldi hallgatók jelentette kihívást. Úgy vélekednek, hogy ezek, ha természettudományokat tanítanak, őket nem érintik, hiszen például „a kémiában az oxigén mindenütt ugyanaz”. A második szakasz az áthárítás, amikor már érzékelik a kihívásokat, de úgy gondolják, hogy a külföldi hallgatókat másoknak kell alkalmassá tenniük. „Először ti megjavítjátok, aztán én megtanítom őket.” A harmadik szakaszban elvárják, hogy a hallgatók alkalmazkodjanak. „Ők akartak itt tanulni, nekik kell idomulniuk a mi oktatási rendszerünkhöz.” A negyedik szakaszban az oktatók befogadják a külföldi hallgatókat és tanítási módszereiket hozzájuk igazítják. „Ők az én hallgatóim. Lássuk, mit hoztak, és mit kell nekem tennem, hogy eredményesek legyenek.” 
Az egyéni, oktatói szint mellett intézményi szinten is megfelelően kell viszonyulni a külföldi hallgatók megjelenéséhez. Ennek egyik eleme az úgynevezett deficit-szemlélettól való elmozdulás. A deficit-szemlélet szerint a külföldi hallgatók képviselte másság, deviancia, a normálistól való eltérés, probléma, amit meg kell oldani. A megoldás pedig az, hogy megpróbálják „felhozni” őket, hogy megfeleljenek a fogadó oktatási rendszer standardjainknak és tanítási modelljeinknek. Egege és Kutieleh megfigyelése szerint a legtöbb, külföldi hallgatók támogatását szolgáló program ezen a célkitűzésen alapul. Ehelyett el kellene ismerni, hogy a tanuláshoz többféle, egyformán legitim viszonyulás létezik, és ab ovo egyik sem tekinthető érvényesebbnek, mint a másik. Megítélésüket kell, hogy befolyásolja az a szokásrendszer, amiben gyakorolják, és az, hogy miként segíti a közösen kívánt tanulási eredmények elérését. A kulturálisan beágyazott tanulásfelfogások maradéktalan elfogadása nem helyezhető fenntartások nélkül az eredményesség fölé. Ebből a megközelítésből az a célkitüzés következik, hogy minden hallgatót a saját kulturális határain, paradigmáin belül tanítsanak. A külföldi hallgatók ne érezzék azt, hogy a saját kulturális és akadémiai értékeik veszélybe kerülnek. (Egege, Kutieleh 2004) Vannak, akik kritikusan tekintenek arra az álláspontra, hogy mindenkire ugyanazok a standardok vonatkoznak, és a különleges bánásmódot a minimálisra kell csökkenteni. (Smith 1998 idézi Ward 2006) Volet és Renshaw (1995 idézi Ward 2006) szerint a hallgatók teljesítményét abban a kontextusban kell tekinteni, amelybe ágyazódva elérték azt.

\section{Lehetőségek - a külföldi hallgatók jelenlétének pozitív kulturális hatásai}

A nemzetköziesítés ezen formájának, a külföldi hallgatók fogadásának legfontosabb hozadéka kulturális szempontból, hogy a hazai hallgatók szembesülnek más kultúrákkal (Aston 1996 idézi Ward 2006), kulturálisan sokszínű közegben szereznek tapasztalatokat, a külföldi hallgatók gyakorlatilag „helybe hozzák” a hazai egyetemisták számára a világot. Ennek nálunk azért van különösen nagy jelentősége, mert a hazai hallgatók kiutazási hajlandósága - például az Erasmus+ mobilitási rendszerben - csekélyebb a kívánatosnál. A kutatások igazolják, hogy az interkulturális csoportmunka csökkenti a sztereotípiákat és növeli a hajlandóságot a más kultúrából érkezőkkel való együttmúködésre (Ward 2006). Az „élő” tapasztalat nyitottá, empatikussá, magabiztossá teszi a hallgatókat a más kultúrájúakkal való interakciókban. Ahogyan Knight fogalmaz: a mai hallgatóknak egyre nagyobb szükségük van az interkulturális munkakompetenciákra: „érteniük kell a nemzetközi és globális jelenségeket, interkulturális kompetenciákat kell használniuk még akkor is, ha soha nem hagyják el a saját országukat" (Knight 2012: 23). A Magyarországon megjelenő külföldi tőke, multinacionális vállalatok révén az itthon dolgozóknak is nemzetközi közegben kell boldogulniuk. Emellett számos magyar állampolgár települ le külföldön, esetükben a gyorsabb beilleszkedést segítheti az itthon szerzett multikulturális tapasztalat. A szakirodalomban ezt a világpolgárságra ( $g l o b a l$ citizenship) való felkészítésként definiálják (Diaz et al. 1999). Több kutatás kiemeli a tanuláshoz való hozzáállás javulását a hazai hallgatók körében, a külföldi hallgatók hozzáállása következtében, ami szintén kulturálisan meghatározott.

Jourdini (2012) felmérésében a következő előnyöket említette a külföldi hallgatók jelenlétével kapcsolatban:

- A külföldi hallgatókkal való személyes kontaktusokon keresztül könnyű megismerni más kultúrákat a kampuszon.

- Ezáltal az amerikai hallgatók a saját kultúrájukra is tudatosabban tekintenek, tágabb perspektívában tudják szemlélni saját helyzetüket.

- A külföldi hallgatókkal való kapcsolatok révén toleránsabbak lesznek más rasszhoz és etnikai csoporthoz tartozó emberekkel.

Leask szerint “a kulturálisan sokszínủ kampusz kiváló lehetőségeket kínál a hallgatóknak, hogy olyan kompetenciákat szerezzenek, amelyek révén eredményesen boldogulnak a globális közösségben. A kulturális mássággal való találkozás hozzájárulhat ahhoz, hogy az új, a kihívást jelentő, az ismeretlen legyen a norma, az addig biztosra vehető megkérdőjeleződjön, új gondolatok és gondolkodásmód honosodjanak meg" (Leask 2009: 219). Mindezek természetesen nem csak a hallgatókra, hanem az oktatókra is igazak. 
Hasonlók a magyar tapasztalatok is. „A mobilitásban közvetlenül részt nem vevő hazai diákok számára egyedülálló lehetőséget jelent a bejövő külföldi diákokkal való közös tanulás, szabadidő-eltöltés, a kultúraközi nyitottság erősítése” (Kisbáró et al.: 39). Az így szerzett „élő tapasztalat” a sztereotípiákat is lebontja. (Tempus 2019b: 25) „A magyar hallgatóknak lehetősége nyílik a saját egyetemükön belül új kultúrákat megismerni. Az ilyen hallgatók empatikusabbak, nyitottabbak lesznek, illetve a külföldiek ösztönzik őket, hogy ők is merjenek utazni, világot látni” (Malota 2013: 82-83).

Ugyanakkor a külföldi hallgatók puszta jelenléte nem generálja a fentebb részletezett pozitív változásokat. A nemzetközi és a hazai felmérések is azt mutatják, hogy a hazai és a külföldi hallgatók jelentős mértékben elkülönülnek egymástól. (Lásd például Andrade, Evans 2009; Leask 2009; Ward 2006; Tempus 2019b.) Ennek részben jogi, oktatásszervezési okai vannak, részben a korábban már tárgyalt kulturális gettósodás áll mögötte, melyet nem csak a külföldi hallgatók összetartása, hanem például a magyar hallgatók idegennyelvi bizonytalansága is erősít. Ezért az intézményeknek - a jogi kereteken belül - minden lehetőséget ki kell használniuk a külföldi és a hazai hallgatók interakcióinak biztosítására, ösztönzésére. „Tudatosan kell megszervezni a külföldi hallgatók integrációját, ugyanis ez spontán módon nem fog kialakulni” (Tempus 2019b: 12).

Fontos azonban azt is leszögezni, hogy önmagában az együttlét sem feltétlenül vezet interkulturális tanuláshoz. Az úgynevezett kontaktuselméletet, mely szerint az egymástól tanulás automatikusan bekövetkezik, ha a különböző kulturális hátterű emberek kellő ideig és kellő intenzitással érintkeznek, sokan cáfolták. Tennivaló tehát nem csak intézményi szinten, hanem a tantermekben, a tanítási-tanulási folyamatok szintjén is van. Az egymástól tanulás ugyanis csak akkor következik be, ha megfelelően facilitálják (Otten 2000). Ahhoz, hogy a megvalósuljon az interkulturális tanulás, megfelelő tanítási stratégiák szükségesek, amelyek integrálják a hallgatók kulturális inputjait, erőforrásként használják a hallgatók eltérő kulturális hátterét (Teekens 2003). További feltétel, hogy a tanulási folyamatot tudatosan úgy tervezzék, hogy az minél inkább interaktív és kollaboratív legyen (Van der Wende 2000 idézi Yefanova et al. 2015). Az oktatóknak fejleszteniük kell a hallgatók készségeit, szokásait, eszköztárát az érdemi és elfogadáson alapuló interakciókhoz (Lee et al. 2014 idézi Yefanova et al. 2015). „Az interkulturális kapcsolódás az elfogadás, empátia, hitelesség, megértés és megértettség megtapasztalásának légkörében jöhet csak létre" (Tempus 2019b: 25). A nemzetközi diverzitást fel kell használni a tananyag elsajátításához (Yefanova et al. 2015); olyan feladatokat kell adni, amelyeket nem lehet megoldani kulturális információcsere nélkül (Leask 2009).

\section{Összegzés, következtetések}

Tanulmányunkban a külföldi hallgatókkal kapcsolatos kulturális kihívásokat, az interkulturális tanuláshoz szükséges feltételeket, és a nemzetközi tantermek, kampuszok jelentette lehetőségeket, kulturális hatásokat foglaltuk össze nemzetközi és hazai szakirodalmi források, kutatások alapján. A kihívások kapcsán tárgyaltuk a kulturális sokk, a kulturális gettósodás jelenségét, kitértünk az akadémiai kultúrák eltéréseiből adódó nehézségekre is. A feltételek kapcsán számba vettük a nemzetközi tanteremben történő tanításhoz szükséges legfontosabb interkulturális kompetenciákat, ezen belül az attitűd-, a tudás- és a képesség-elemeket. Szervezeti szinten a deficit-elmélettől való elszakadás fontosságáról és a külföldi hallgatókkal kapcsolatos helyes intézményi hozzáállásról írtunk. A lehetőségekkel kapcsolatban az interkulturális kompetenciák megszerzésének fontosságát, a sztereotípiák leépítését, a világpolgárságra való felkészítést emeltük ki. Rámutattunk, hogy a külföldi hallgatók puszta jelenléte nem generálja ezeket a kedvező változásokat; az interkulturális tanuláshoz mind szervezeti, mind tantermi szinten tudatos cselekvésre van szükség. E megállapítások jelentôs része nem csak a külföldi hallgatókra, a nemzetközi tantermekre vonatkoztatható; minden intézményben, tanteremben releváns lehet, amely bármilyen szempontból multi- illetve interkulturális tanulási környezetnek tekinthető.

A hazai felsőoktatás a nemzetköziesítés tekintetében jelenleg a mennyiségi növekedés fázisából a minőségi fejlődés fázisába tart. Ezt mutatja, hogy számos intézményben már nem a külföldi hallgatók létszámának növelése a cél, hanem a jobb „merítés”, felkészültebb hallgatók beiskolázása egyre kifinomultabb és szigorúbb kiválasztási mechanizmusokkal. További eleme 
az átmenetnek, hogy a kihívást immár nem az angolul előadni képes oktatói bázis biztosítása, hanem a nemzetközi képzésen tanítók minél jobb és átfogóbb felkészítése jelenti. Ebbe az interkulturális tréningek is beletartoznak. Szintén a minőség felé történő elmozdulás jele, hogy a külföldi hallgatóknak nyújtott szolgáltatások már nem merülnek ki az alapdokumentumok angolra fordításában és az albérletszerzésben, hanem kiegészülnek „buddy”, azaz mentorprogrammal, angol nyelvi fejlesztéssel, pszichológiai tanácsadással.

A sikeres átmenethez elengedhetetlenül szükséges a külföldi hallgatókkal kapcsolatos kulturális kihívásokkal történő szembenézés, a globalitás, a multikulturalizmus paradigmájának beemelése a szervezeti kultúrába, értékrendbe, az oktatók, adminisztratív dolgozók és hazai hallgatók interkulturális kompetenciáinak fejlesztése, párbeszéddel kísért, interaktív, valós helyzeteket szimuláló, gyakorlatias tréningekkel, esetmegbeszélésekkel. A külföldi hallgatók jelenlétének kedvező kulturális hatásai akkor fognak erőteljesen érvényesülni, ha az intézmények és az oktatók erőforrásként tekintenek a diverzitásra, tudatosan tervezett programokkal, intézkedésekkel segítik elő a külföldi hallgatók integrációját, az oktatók tudatosan tervezett és alkalmazott pedagógiai módszerekkel segítik elő az interkulturális tanulást.

\section{Irodalom}

Adler, N. J. (1991). International Dimensions of Organizational Behaviour, 2nd edition, PWS-Kent.

Andrade, M. S., Evans, N. W. (2009). International students: Strengthening a critical resource. Lanham: Rowman \& Education.

Aston, B. (1996). Students from Asia in New Zealand secondary schools. Kézirat.

Ballard, B. (1995). Some Issues in Teaching International Students. In: Conrad, L., Phillips, L. (szerk.). Reaching More Students, 107-114. Griffith Institute for Higher Education.

Bedenlier, S., Zawacki-Richter, O. (2015). Internationalization of higher education and the impacts on academic faculty members. Research in Comparative \& International Education, 10(2), 185201.

Berács J., Bander K., Hubert J., Nagy G., Temesi J. (2014). A felsőoktatási mobilitást akadályozó és ösztönző tényezők Magyarországon 1. kötet. Tempus Közalapítvány, Budapest.

Berács J., Malota E. (2011). Megéri hozzánk jönni tanulni? Educatio 2011/2, 220-234.

Biggs, J. (1997). Teaching Across and Within Cultures: The Issue of International Students. In: MurrayHarvey, R., Silins, H.C. (szerk.). Learning and Teaching in Higher Education: Advancing International Perspectives. Proceedings of the Higher Education Research \& Development Society of Australasia Conference, Adelaide: Flinders Press.

Bowry, C. (2002). An Initial Exploration of the Impact of Foreign Students on the Education of Domestic Students at Queen's University. Queen's University https://www.collectionscanada.gc.ca/obj/s4/f2/dsk3/ftp05/MQ65606.pdf. Utolsó letöltés: 2020. 11. 20.

Carroll, J. (2012). Teaching international students: Strategies for enhancing students' learning. https://www.dkit.ie/system/files/Jude\%20Carroll\%20Talk\%202\%20Strategies\%20for\%20en hancing\%20students\%E2\%80\%99\%20learning\%20Oct\%2012.ppt.pdf. Utolsó letöltés 2020. november 10 .

Deardorff, D. K. (2009). The Sage handbook of intercultural competence. Sage Publication, Inc.

Diaz, C. F., Massialas, B. G., Xanthopoulos, J. A. (1999). Global perspectives for educators. Needham Heights, Allyn \& Bacon.

Dunn, L., Wallace, M. (2006). Australian academics and transnational teaching: An exploratory study of their preparedness and experiences. Higher Education Research \& Development, 25(4), 57-369.

Egege, S., Kutieleh, S. (2004). Critical Thinking: Teaching Foreign Notions to Foreign Students. International Education Journal, Vol 4, No 4, 75-85.

Ellis, D. G. (2006). Transforming conflict: Communication and ethnopolitical conflict. Rowman \& Littlefield Publishers, Inc.

Erdei L., Verderber É., Horváth L., Velkey K., Kovács I., Kálmán O. (2018). Nemzetközi együttműködésben megvalósuló doktori képzések mint a szervezeti tanulás forrásai. $U j$ Pedagógiai Szemle 2018/1-2.

Erdei Luca (2018). Nemzetköziesítés a mesterképzésben. Educatio 27 (3), 490-497

Godwin, K. A. (2009). Academic culture shock. New England Journal of Higher Education, 23(5), 30.

Gopal, A. (2011). Internationalization of Higher Education: Preparing Faculty to Teach Crossculturally. International Journal of Teaching and Learning in Higher Education. Vol. 23, No 3, 373-381. 
Hangyál Zs., Kasza G. (2018). Stipendium Hungaricum ösztöndíjas hallgatók helyzete, véleménye, elvárásai. Tempus Közalapítvány, Budapest.

Hiller, G. G., Wozniak, M. (2009). Developing an intercultural competence programme at an international cross-border university. Intercultural Education, 20(4), 113-124.

Jourdini, M. M. (2012). The Impact Of International Students On American Students And Faculty At An Appalachian University. Eastern Kentucky University. https://encompass.eku.edu/cgi/viewcontent.cgi?article=1106\&context=etd. Utolsó letöltés: 2020. 11. 01.

Kim, M. S., Hubbard, A. S. E. (2007). Intercultural communication in a global village: How to understand "the other". Journal of Intercultural Communication Research, 36(3), 223-235.

Kisbáró E., Kovács I. V., Kovács L., Mester-Takács T., Mészáros G., Somoskői G. (2015). Felsőoktatási nemzetköziesítési törekvések. Tempus Közalapítvány, Budapest.

Knight, J. (2012). Student Mobility and Internationalization: trends and tribulations. Research in Comparative and International Education Vol. 7 No. 1. 20-33.

Kovács I. V., Tarrósy I., Kovács K. (2015). A felsőoktatás nemzetköziesítése. Tempus Közalapítvány, Budapest.

Lannert J. (2018a): Nemzetközi hallgatók a hazai felsőoktatási intézményekben. Tempus Közalapítvány, Budapest.

Lannert J. (2018b): A doktori iskolák nemzetköziesedésének vizsgálata. Tempus Közalapítvány, Budapest.

Leask, B. (2009). Using Formal and Informal Curricula to Improve Interactions Between Home and International Students. Journal of Studies in International Education 2009/13., 205-221.

Lee, A., Williams, R. D., Shaw, M. A., Jie, Y. (2014). First-year students' perspectives on intercultural learning. Teaching in Higher Education, 19(5), 14-18.

Lemke-Westcott, T., Johnson, B. (2013). When culture and learning styles matter: A Canadian university with Middle Eastern students. Journal of Research in International Education 12(1), 66-84.

Malota E. (2013). Intézményi nemzetköziesítés és a nemzetköziesítést célzó kurzusok a belföldi hallgatók szemével. Tempus Közalapítvány

Malota E., Bereczki N., Bander K., Borgström M., Berács J., Futó J. (2014). A felsőoktatási mobilitást akadályozó és ösztönző tényezők Magyarországon 2. kötet. Tempus Közalapítvány, Budapest.

Malota E. (2016). Hallgatói véleményfelmérés 2016. Magyarország és a magyar felsőoktatás a külföldi hallgatók szerint. Tempus Közalapítvány, Budapest.

Mills, C. (1997). The lived-in realities of internationalisation. In: Murray-Harvey, R., Silins, H.C. (szerk.). Learning and Teaching in Higher Education: Advancing International Perspectives. Proceedings of the Higher Education Research \& Development Society of Australasia Conference, Adelaide, 91-114, Flinders Press.

Nilsson, J. E., Anderson, M. Z. (2004). Supervising International Students: The Role of Acculturation, Role Ambiguity, and Multicultural Discussions. Professional Psychology: Research and Practice Vol. 35, No. 3, 306-312.

Otten, M. (2000). Impacts of cultural diversity at home. In: Crowther et al. (szerk.). Internationalisation at Home. European Association for International Education.

Paige, R. M., Goode, M. L. (2009). Cultural mentoring: International education professionals and the development of intercultural competence. In: Deardorff, D. K. (szerk.). The Sage handbook of intercultural competence 333-349. Sage Publications, Inc.

Potts. J. D. (1992). International students at Fort Hays Universitv: An impact analvsis. National Association of Foreign Student Advisors.

Rizvi, F. (2010). International students and doctoral studies in transnational spaces. In: Walker, M., Thomson, P. (szerk.). The Routledge doctoral supervisor's companion: Supporting effective research in education and the social sciences 158-170. Routledge.

Ryan, J. (2011). Teaching and Learning for International Students: towards a transcultural approach, Teachers and Teaching, 17(6), 631-648.

Smith, A. (1998). New survey reveals changing attitudes. American Language Review, 2, 28-29.

Teekens, H. (2003). The requirement to develop specific skills for teaching in an intercultural setting. Journal of Studies in International Education, 7(1), 108-119.

Tempus (2017). Erasmus Mundus mesterképzések. Tempus Közalapítvány, Budapest. http://www.tka.hu/palyazatok/736/erasmus-mundus-kozos-mesterkepzesek

Tempus (2019a): Nemzetköziesítünk. Felsőoktatási intézmények nemzetköziesítési jó gyakorlatai 1. Tempus Közalapítvány

Tempus (2019b): Nemzetköziesítünk. Felsőoktatási intézmények nemzetköziesítési jó gyakorlatai 2. Tempus Közalapítvány

Tempus (2019c): Nemzetköziesítünk. Felsőoktatási intézmények nemzetköziesítési jó gyakorlatai 3. Tempus Közalapítvány, Budapest. 
Tempus (2020a): A befelé irányuló felsőoktatási mobilitás gazdasági hatásainak mérése. Tempus Közalapítvány, Budapest.

Tempus (2020b): Nemzetköziesítünk. Felsőoktatási intézmények nemzetköziesítési jó gyakorlatai 4. Tempus Közalapítvány, Budapest.

Van der Wende, M.C. (2000). The Bologna Declaration: Enhancing the Transparency and Competitiveness of European Higher Education. Higher Education in Europe, 25(3), 305310.

Verbik, L. (2007). The international branch campus: Models and trends. International Higher Education, 46, 1-2.

Volet, S., Renshaw, P. D. (1995). Cross-cultural differences in university students' goals and perceptions of study settings for achieving their own goals. Higher Education, 30, 407-433.

Ward, C. (2006). International Students: Interpersonal, Institutional and Community Impacts. Ministry of Education New Zeland https://www.researchgate.net/publication/237453029_Research_Report_International_Stu dents_Interpersonal_Institutional_and_Community_Impacts. Utolsó letöltés: 2020.11. 15.

Yefanova, D., Baird, L., Montgomery, M. L. (2015). Study of the Educational Impact of International Students in Campus Internationalization at the University of Minnesota. Phase One - Focus Groups and Interviews Over-Arching Report on Phase One Findings https://global.umn.edu/icc/documents/15_EducationalImpact-IntlStudents.pdf. Utolsó letöltés: 2020. 11. 30. 